\title{
MODEL PEMBELAJARAN SAINS TEKNOLOGI MASYARAKAT (STM), KETERAMPILAN SOSIAL, DAN HASIL BELAJAR IPS
}

\author{
Putu Asih Ardani ${ }^{1}$, I Wayan Lasmawan², I Gd. Astra Wesnawa ${ }^{3}$ \\ Program Studi Pendidikan IPS Universitas Pendidikan Ganesha Singaraja \\ e-mail: asih.ardanii@gmail.com ${ }^{1}$, lasmawan wayan@pasca.undikhsa.ac.id ${ }^{2}$ \\ gede astra@pasca.undikhsa.ac.id ${ }^{3}$
}

\begin{abstract}
Abstrak
Penelitian ini dilaksanakan di SMP Negeri 12 Denpasar dengan tujuan (1) untuk menganalisis perbedaan keterampilan sosial antara siswa yang mengikuti pembelajaran dengan model pembelajaran STM dan siswa yang mengikuti pembelajaran konvensional pada siswa Kelas VII SMP Negeri 12 Denpasar, (2) Untuk menganalisis perbedaan hasil belajar IPS antara siswa yang mengikuti pembelajaran dengan model pembelajaran STM dan siswa yang mengikuti pembelajaran konvensional pada siswa Kelas VII SMP Negeri 12 Denpasar, (3) untuk menganalisis perbedaan secara simultan keterampilan dan hasil belajar IPS antara siswa yang mengikuti pembelajaran dengan model pembelajaran STM dan siswa yang mengikuti pembelajaran konvensional pada siswa Kelas VII SMP Negeri 12 Denpasar. Populasi dalam penelitian ini adalah seluruh siswa kelas VII SMP Negeri 12 Denpasar tahun pelajaran 2017/2018 berjumlah 314 orang yang tersebar di delapan kelas, sampel penelitian dengan random sampling, ditentukan kelas $\mathrm{VII}_{\mathrm{A}}$ terpilih sebagai kelas eksperimen dan kelas VIID sebagai kelas kontrol dengan jumlah masing-masing sampel 40 orang. Data dikumpulkan dengan kuesioner dan tes. Data dianalisis dengan anava dan manova satu jalur dengan uji $F$. Hasil penelitian menunjukkan bahwa: (1) terdapat perbedaan keterampilan sosial siswa antara yang mengikuti pembelajaran dengan model pembelajaran STM dan konvensional dengan $F_{\text {hitung }}=19,414$ $(p=0,000<0,05)$. Dengan demikian dapat dinyatakan bahwa model pembelajaran STM berpengaruh terhadap keterampilan sosial siswa, (2) terdapat perbedaan hasil belajar IPS siswa antara yang mengikuti pembelajaran dengan model pembelajaran STM dan konvensional dengan $F_{\text {hitung }}=8,006(p=0,0066<0,05)$. Dengan demikian dapat dinyatakan bahwa model pembelajaran STM berpengaruh terhadap hasil belajar IPS siswa, dan (3) terdapat perbedaan keterampilan sosial dan hasil belajar IPS siswa antara yang mengikuti pembelajaran dengan model pembelajaran STM dan konvensional dengan FWiks' Lambda $=14,980 \quad(p=0,000<0,05)$. Dengan demikian dapat dinyatakan bahwa model pembelajaran STM berpengaruh secara simultan terhadap keterampilan sosial dan hasil belajar IPS siswa.
\end{abstract}

Kata kunci: model pembelajaran STM, pembelajaran konvensional, keterampilan sosial, hasil belajar IPS

\section{Abstract}

This research was conducted at SMP Negeri 12 Denpasar with the aim (1) to analyze the difference of social skill between students who followed the learning with CTS learning model and students who followed conventional learning at Seventh Grade Students of SMP Negeri 12 Denpasar, (2) to analyze the difference of IPS learning result between students who followed the learning with CTS learning model and students who followed the conventional learning at Seventh Grade Students of SMP Negeri 12 Denpasar, (3) to analyze the difference simultaneously skills and learning outcomes between students who follow the learning with CTS learning model and students who follow the conventional learning at Seventh Grade Students of SMP Negeri 12 Denpasar. The population in this study is all students of Seventh Grade of SMP Negeri 12 Denpasar in academic year 2017/2018 amounted to 314 student spread in eight classes with ramdom sampling, the grade VIIA was selected as the experimental class and the grade VIID as the control class with the sum of 40 samples each. Data were collected with questionnaires and tests. The data were analyzed by one-way ANOVA and manova with $F$ test. The results showed that: (1) there was difference of social skill between students who followed CTS learning and conventional learning model with Fhitung $=19,414(p=0,000<0,05)$. Thus, it can be stated that the learning model of CTS has an effect on the students' social skills, (2) there is difference of learning result of students' IPS between those who follow the learning with CTS and 
conventional learning model with Fcount $=8,006(p=0,0066<0,05)$. Thus, it can be stated that the CTS learning model has an effect on the students' social skills, (2) there is difference of learning result of students' IPS between those who follow the CTS learning model and conventional learning model with Fcount $=8,006(p=0,0066<0,05)$. Thus, it can be stated that the CTS learning model has an effect on the student's learning outcomes, and (3) there is difference of social skill and learning result of students' IPS between those who follow the CTS learning and conventional learning model with FWilks' Lambda $=14,980(p=0,000<0,05)$. Thus it can be stated that the learning model of CTS simultaneously affect the social skills and learning outcomes of students's IPS

Keywords : $\quad$ CTS learning model, conventional learning, social skills, IPS learning outcomes

\section{PENDAHULUAN}

Pembelajaran IPS sebagai salah satu program pendidikan yang membina dan menyiapkan peserta didik sebagai warga negara yang baik dan memasyarakat diharapkan mampu mengantisipasi berbagai perubahan yang terjadi di masyarakat sehingga siswa mempunyai bekal pengetahuan dan keterampilan dalam melakoni kehidupan di masyarakat. Guru dituntut untuk mampu mengikuti dan mengantisipasi berbagai perubahan masyarakat tersebut, sehingga program pembelajaran yang dilakukannya dapat membantu siswa dalam mempersiapkan dirinya sebagai warga masyarakat dan warga negara untuk memecahkan berbagai persoalan yang dihadapi dalam kehidupannya sehari-hari

Guru harus cermat dalam memilih model pembelajaran dan merancang program serta strategi pembelajaran, sehingga pembelajaran yang dilakukannya menjadi pembelajaran yang menarik, aktual, dan fungsional bagi siswa. Pemilihan model pembelajaran oleh guru mempunyai dampak yang sangat esensial bagi perolehan belajar siswa. Kondisi pembelajaran IPS di Indonesia dewasa ini lebih diwarnai oleh pendekatan yang menekankan pada model belajar konvensional yang lebih banyak diwarnai dengan ceramah, sehingga kurang mampu merangsang siswa untuk terlibat secara aktif dalam proses belajar-mengajar (Suwarma, 1991). Suasana belajar seperti ini semakin menjauhkan peran IPS dalam upaya mempersiapkan warga negara yang baik dan mampu bermasyarakat. Kondisi pembelajaran IPS dewasa ini khususnya pada jenjang sekolah menengah pertama, menunjukkan indikasi bahwa pola pembelajaran yang dikembangkan oleh guru cenderung bersifat guru sentris sehingga siswa hanya menjadi objek pembelajaran.

Kondisi pembelajaran seperti di atas jelas tidak mendorong pengembangan potensi diri siswa dalam pembelajaran, sehingga hasil belajar yang dicapai oleh siswa juga tidak optimal, karena guru hanya mencekoki pikiran siswa dengan konsep-konsep materi pelajaran yang bersifat hafalan saja, kemudian dalam melakukan evaluasi juga hanya mengevaluasi materi yang diberikannya. Pembelajaran seperti itu, nampaknya tidak mampu menunjang dan mendorong siswa untuk mengaktualisasikan potensi dirinya secara optimal. Suasana belajar yang demikian mendorong lahirnya pola interaksi yang searah yaitu hanya dari guru ke siswa saja, sehingga akan mematikan kreativitas dan menghambat pengembangan potensi diri siswa. Model pembelajaran yang demikian, lebih cendrung berangkat dari asumsi dasar bahwa pembelajaran IPS hanya dimaksudkan untuk mentransfer pengetahuan atau konsep dari kepala guru ke kepala siswa. Akibatnya, mungkin guru telah merasa membelajarkan namun siswa belum belajar. Konsekuensi logis dari pola pembelajaran yang demikian pada dasarnya sudah merupakan pengingkaran terhadap tujuan dan peran kritis yang diemban oleh IPS.

Berdasarkan indikator-indikator tersebut, nampaknya kualitas proses pembelajaran IPS dewasa ini masih sangat rendah. Kondisi pembelajaran IPS sebagaimana yang diuraikan di atas, menyebabkan siswa kurang bergairah dalam mempelajari IPS, karena siswa hanya akan berusaha menghafal materi yang diberikan oleh guru, tanpa berusaha mencari dan mengembangkan pengetahuan dan pemahamannya pada hal-hal lain yang 
baru untuk menunjang dan memantapkan pemahaman mereka mengenai materi IPS. Implikasi semua itu adalah keterampilan sosial dan hasil belajar IPS siswa belum optimal.

Keberhasilan suatu pendidikan tidak hanya diukur dari pencapaian kognitif saja, tetapi yang lebih penting juga adalah segi afektif dan perilaku. Sikap saling menghormati dan menghargai dalam interaksi sosial baik di dalam sekolah maupun di luar sekolah seharusnya juga perlu mendapatkan perhatian. Oleh karenanya, keterampilan sosial sangat perlu diajarkan di sekolah. Hal ini selaras dengan apa yang dikatakan oleh Muijs dan Reynolds (2008: 280) bahwa keterampilan sosial termasuk tujuan utama pendidikan untuk meningkatkan kesiapan sekolah seperti kemampuan untuk menghormati orang lain, untuk bekerja sama secara kooperatif, untuk mengekspresikan emosi dan perasaan dengan cara yang baik, untuk mendengarkan orang lain, untuk mengikuti aturan dan prosedur, untuk duduk dengan penuh perhatian, dan untuk bekerja secara mandiri.

Berdasarkan analisis empirik terhadap kondisi pembelajaran IPS di sekolah menengah pertama dan kajian terhadap tujuan, esensi, dan peran kritis yang diemban oleh IPS, nampaknya persoalan tersebut memerlukan suatu alternatif pemecahan yang sangat mendesak untuk menjembatani persoalan-persoalan seputar proses pembelajaran IPS khususnya pada jenjang sekolah menengah pertama. Artinya, diperlukan upaya-upaya yang terprogram untuk mengubah dan memperbaiki pola pembelajaran yang selama ini dikembangkan dan dilaksanakan oleh guru berdasarkan hasil kajian secara empiris dan pragmatis tentang realita yang terjadi di lapangan. Upaya tersebut dimaksudkan agar proses pembelajaran IPS yang dilakukan oleh guru dapat mencerminkan pola interaksi belajar yang kondusif dan mendukung pengembangan potensi diri siswa secara optimal (NCSS, 2007).

Salah satu alternatif yang diduga mampu menjembatani persoalan tersebut adalah dengan melakukan inovasi pada model pengorganisasian materi, model pembelajaran, buku ajar, dan perangkat penilaian IPS, agar pembelajaran yang dilakukan dan dikembangkan oleh guru dapat memfasilitasi perkembangan potensi siswa secara optimal dan mampu melatih ketertanggapan sosial siswa terhadap berbagai masalah yang tumbuh dan berkembang di masyarakat yaitu melalui pembelajaran dengan model sain teknologi masyarakat (STM). Prayekti (2001) menyatakan bahwa model pembelajaran STM memungkinkan siswa berperan secara aktif dalam pembelajaran dan dapat menampilkan peranan sains dan teknologi di dalam kehidupan masyarakat. Demikian pula Nurdin (2005: 42) menyatakan bahwa untuk dapat mengorganisasikan pembelajaran yang lebih bermakna dan menyentuh realita kehidupan siswa, antara lain dengan mengembangkan pembelajaran STM. Hal itu akan memberikan makna bahwa pembelajaran IPS berkaitan dengan kehidupan siswa atau manusia sehari-hari sehingga perlu dikembangkan pembelajaran yang sesuai dengan realita kehidupan siswa. Pembelajaran bukan hanya mentransfer ilmu pengetahuan saja, tetapi juga berkaitan dengan bagaimana siswa mampu memahami dampak dari pembelajaran atau hasil pembelajaran tersebut baik dampak positif maupun negatifnya. Untuk itu meodel STM dicobakan dalam penelitian ini sebagai eksperimen dalam upaya meningkatkan keterampilan sosial dan hasil belajar IPS siswa.

Variabel terikat dalam penelitian ini adalah keterampilan sosial dan hasil belajar IPS yang dipengaruhi model pembelajaran STM dan pembelajaran konvensional. Keterampilan sosial kemampuan seseorang untuk berani berbicara, mengungkapkan setiap perasaan atau permasalahan yang dihadapi sekaligus menemukan penyelesaian yang adaptif, memiliki tanggung jawab yang cukup tinggi dalam segala hal, penuh pertimbangan sebelum melakukan sesuatu, mampu menolak dan menyatakan ketidaksetujuannya terhadap pengaruh-pengaruh negatif dari lingkungan. Pengukuran ketarampilan sosial melibatkan 5 (lima) dimensi: yaitu: (1) peer relational skills (keterampilan berhubungan dengan teman sebaya), (2) self-management skills (keterampilan pengaturan diri), (3) akademic skills (keterampilan akademik), (4) compliance skills (keterampilan kepatuhan), dan (5) assertion skills (keterampilan penegasan), Caldarella dan Merrell (Gimpel \& Merrell, 1998).

Hasil belajar mata pelajaran IPS adalah segenap perubahan perilaku yang terjadi pada peserta didik berkenaan dengan bidang IPS sebagai hasil dari mengikuti proses pembelajaran mata pelajaran IPS. Pencapaian hasil belajar dalam hal penguasaan konsep IPS, menunjukkan perubahan dalam dimensi kognitif, yaitu seberapa jauh siswa mencapai 
perubahan dalam pengetahuan atau pemahamannya tentang IPS, dalam arti fakta, konsep, prinsip, hukum dan teori. Secara operasional, hasil belajar mata pelajaran IPS yang dimaksud dalam penelitian ini skor yang diperoleh siswa dalam menjawab tes hasil belajar IPS dalam bentuk tes objektif yang menggambarkan kemampuan kognitif selama mengikuti pelajaran.

\section{METODE PENELITIAN}

Penelitian ini dikatagorikan eksperimen semu (kuasi eksperimen). Desain ini dipilih karena eksperimen dilakukan di beberapa kelas tertentu dengan siswa yang telah ada atau sebagaimana adanya. Rancangan eksperimen yang dipilih adalah rancangan post test only control group design. Populasi dalam penelitian ini adalah semua siswa kelas VII SMP Negeri 12 Denpasar, dengan jumlah 314 orang yang tersebar dalam delapan kelas pararel. Berdasarkan hasil kesetaraan semua kelas VII SMP Negeri 12 Denpasar memiliki kemampuan yang setara maka bisa dilakukan dengan random sampling. Dua kelas dijadikan sampel penelitian, satu kelas sebagai kelas eksperimen dan satu kelas sebagai kelas kontrol. Data dikumpulkan dengan kuesioner dan tes serta dianalisis dengan anova dan manova satu jalur dengan uji F.

\section{HASIL PENELITIAN DAN PEMBAHASAN}

Untuk permasalahan pertama, hasil analisis dengan analisis varians satu jalur diperoleh bahwa nilai $F_{\text {hitung }}=19,414(p=0,000<0,05)$. Oleh karena itu, hipotesis nol $(\mathrm{Ho})$ yang menyatakan bahwa tidak ada perbedaan keterampilan sosial siswa antara yang mengikuti pembelajaran dengan model pembelajaran STM dan langsung ditolak. Jadi, ada perbedaan keterampilan sosial siswa antara yang mengikuti pembelajaran dengan model pembelajaran STM dan konvensional.

Hasil perhitungan menunjukkan bahwa perbedaan keterampilan sosial siswa yang mengikuti pembelajaran dengan model pembelajaran STM pada siswa kelas VIII SMP Negeri 12 Denpasar dengan skor rata-rata 128,800, sedangkan keterampilan sosial siswa yang mengikuti pembelajaran dengan pembelajaran konvensional pada siswa kelas VII SMP Negeri 12 Denpasar dengan skor rata-rata 115,950. Ternyata skor rata-rata keterampilan sosial siswa yang mengikuti pembelajaran dengan model pembelajaran STM lebih tinggi daripada sikap siswa yang mengikuti pembelajaran dengan pembelajaran konvensional pada siswa kelas kelas VII SMP Negeri 12 Denpasar Bali. Dengan demikian, dapat disimpulkan keterampilan sosial siswa yang mengikuti pembelajaran dengan model pembelajaran STM lebih tinggi daripada siswa yang mengikuti pembelajaran dengan pembelajaran konvensional pada siswa kelas VII SMP Negeri 12 Denpasar.

Keberhasilan suatu pendidikan tidak hanya diukur dari pencapaian kognitif saja, tetapi yang lebih penting juga adalah segi afektif dan perilaku. Sikap saling menghormati dan menghargai dalam interaksi sosial baik di dalam sekolah maupun di luar sekolah perlu mendapatkan perhatian. Oleh karenanya, keterampilan sosial sangat perlu diajarkan di sekolah. Keterampilan sosial termasuk tujuan utama pendidikan untuk meningkatkan kesiapan sekolah seperti kemampuan untuk menghormati orang lain, untuk bekerja sama secara kooperatif, untuk mengekspresikan emosi dan perasaan dengan cara yang baik, untuk mendengarkan orang lain, untuk mengikuti aturan dan prosedur, untuk duduk dengan penuh perhatian, dan untuk bekerja secara mandiri.

Dalam pembelajaran IPS dengan menggunakan model pembelajaran STM, siswa dilibatkan untuk menerapkan konsep-konsep IPS pada kehidupan sehari-hari. Penerapan konsep IPS ada pada teknologi, dengan demikian siswa mengenali teknologi yang ada di sekitarnya. Kemudian dari observasi ke lingkungan siswa menemukan sendiri kesimpulan atau konsep-konsep IPS yang ada. Guru hanya membimbing siswa dalam memperoleh konsep-konsep yang dituju. Dengan demikian pengajaran IPS dengan model pembelajaran STM akan mampu meningkatkan keterampilan sosial siswa secara maksimal, dan meningkatkan sikap literasi terhadap sains dan teknologi.

Proses pembelajaran yang serius kaku tanpa sedikitpun ada nuansa kegembiraan tentulah akan sangat cepat membosankan. Apalagi diketahui bahwa berdasarkan penelitian 
kekuatan rata-rata manusia untuk terus konsentrasi dalam situasi yang monoton hanyalah sekitar 15 menit saja. Selebihnya pikiran akan segera beralih kepada hal-hal lain yang mungkin sangat jauh dari tempat di mana ia duduk mengikuti suatu kegiatan tertentu. Untuk itu, model pembelajaran perlu dikombinasikan dengan ice breaking. Ice breaking adalah kegiatan yang berfungsi untuk mengubah suasana kebekuan dalam kelompok yang berupa permainan atau dapat dinyatakan sebagai salah satu upaya yang bisa dilakukan guru untuk membangkitkan motivasi siswa dalam belajar dan membuat suasana belajar menjadi lebih asyik dan menyenangkan dalam proses pembelajaran.

Dalam pembelajaran IPS dengan menggunakan pembelajaran konvensional, lebih menekankan pada fungsi guru sebagai pemberi informasi. Siswa hanya pasif mendengarkan penjelasan guru tanpa dilibatkan secara aktif dalam pembelajaran. Guru menjelaskan dari konsep, definisi, pengertian sampai pada contoh-contoh. Siswa baru terlibat jika ada soal yang diberikan oleh guru dan lebih bersifat teks book. Kreatifitas siswa kurang berkembang, sehingga akan berakibat pada kurang maksimalnya keterampilan sosial siswa karena sangat jarang memberikan kepada siswa untuk berpendapat. Hasil penelitian ini juga didukung oleh hasil penelitian Nita Tristina (2015), I Wyn. Suarbawa, Ni Wyn. Arini, I Dw. Pt. Raka Rasana (2013)

Hasil penelitian seperti yang disebutkan di atas tampak bahwa model pembelajaran STM berpengaruh terhadap keterampilan sosial siswa. Dengan demikian dapat disimpulkan bahwa terdapat perbedaan keterampilan sosial siswa antara yang mengikuti pembelajaran dengan model pembelajaran STM dan pembelajaran konvensional pada siswa kelas VII SMP Negeri 12 Denpasar terbukti secara teoretis dan empiris

Untuk permasalahan kedua, hasil analisis dengan analisis varians satu jalur sebagaimana diperoleh nilai $F_{\text {hitung }}=8,006(p=0,006<0,05)$. Oleh karena itu, hipotesis nol (Ho) yang menyatakan bahwa tidak ada perbedaan hasil belajar IPS siswa antara yang mengikuti pembelajaran dengan model pembelajaran STM dan langsung pada siswa kelas VII SMP Negeri 12 Denpasar ditolak. Jadi, ada perbedaan hasil belajar IPS siswa antara yang mengikuti pembelajaran dengan model pembelajaran STM dan pembelajaran konvensional pada siswa kelas VII SMP Negeri 12 Denpasar.

Hasil perhitungan menunjukkan bahwa hasil belajar IPS siswa yang mengikuti pembelajaran dengan model pembelajaran STM pada siswa kelas VII SMP Negeri 12 Denpasar dengan skor rata-rata 24,625, sedangkan hasil belajar IPS siswa yang mengikuti pembelajaran dengan pembelajaran konvensional pada siswa kelas VII SMP Negeri 12 Denpasar dengan skor rata-rata 19,375. Ternyata skor rata-rata hasil belajar IPS siswa yang mengikuti pembelajaran dengan model pembelajaran STM lebih tinggi daripada hasil belajar IPS siswa yang mengikuti pembelajaran dengan pembelajaran konvensional pada siswa siswa kelas VII SMP Negeri 12 Denpasar. Dengan demikian, dapat disimpulkan hasil belajar IPS, siswa yang mengikuti pembelajaran dengan model pembelajaran STM lebih tinggi daripada hasil belajar siswa yang mengikuti pembelajaran dengan pembelajaran konvensional pada siswa kelas VII SMP Negeri 12 Denpasar.

Dari hasil uji hipotesis tersebut mengisyaratkan bahwa model model pembelajaran STM lebih unggul dalam meningkatkan hasil belajar IPS daripada model pembelajaran konvensional. Hal ini disebabkan karena dalam pembelajaran IPS dengan model pembelajaran STM, siswa diarahkan untuk literasi sains dan teknologi. Artinya siswa dapat memahami dari segi sains teknologi, dan lingkungan sekitarnya, yang penuh dengan produk teknologi serta dampak-dampak sosial yang ditimbulkannya. Pada dasarnya orang yang memiliki literasi sains dan teknologi, memiliki pemahaman dan kesadaran tentang sains dan teknologi dan tidak sekadar dapat baca dan tulis sains dan teknologi saja. Pemahaman mencakup pemahaman tentang konsep sains dan teknologi, saling keterkaitannya dan dampaknya bagi umat manusia. Adapun kesadaran mencakup unsur sikap dan prilaku yang dapat diamati melalui tindakan atau kecenderungan bertindak.

Model pembelajaran STM dapat juga dikatakan sebagai upaya mendekatkan siswa kepada obyek yang dibahas. Pengajaran yang menjadikan benda yang dibahas secara langsung diharapkan kepada siswa atau siswa dibawa langsung ke alam sekitarnya, disebut sebagai onstention (Barnes dalam Prayekti, 2001:11). Dalam belajar semacam ini siswa 
mencari hubungan kesamaan (similarity relation) sehingga memperoleh kelompok berdasarkan konsep dan teori yang telah dimiliki dan memperoleh pola-pola berdasarkan pengamatan. Hal ini sesuai dengan apa yang dikatakan Gagne (dalam Prayekti, 2001:15) bahwa untuk terjadi belajar pada diri siswa diperlukan kondisi belajar, baik kondisi internal maupun eksternal. Kondisi internal merupakan peningkatan (arising) memori siswa sebagai hasil belajar terdahulu. Memori siswa yang terdahulu merupakan komponen kemampuan yang baru, dan ditempatkannya bersama-sama. Kondisi eksternal meliputi aspek atau benda yang dirancang atau ditata dalam suatu pembelajaran yang termasuk di dalamnya adalah lingkungan. Suatu proses belajar mengajar dikatakan dapat berjalan efektif bila seluruh komponen yang berpengaruh dalam proses belajar mengajar saling mendukung dalam rangka mencapai tujuan. Misalnya penyajian materi menarik, adanya sarana belajar yang memadai, dan memiliki tujuan yang jelas serta sesuai dengan pengalaman anak-anak sehari-hari.

Pembelajaran dengan menggunakan model pembelajaran Sains Teknologi Masyarakat menyajikan isu yang terkait dengan berbagai konsep dan prinsip ilmiah yang sedang dipelajari oleh siswa, dengan demikian, siswa belajar IPS seolah-olah belajar dekat dengan lingkungan sosial. Hal ini menunjukkan bahwa belajar IPS tidak hanya merupakan hapalan saja melainkan kelihatan manfaatnya dalam kehidupan sehari-hari. Kenyataan ini akan mendorong siswa untuk memecahkan masalah-masalah sosial yang terkait dengan permasalahan sehari-hari. Dengan adanya keterkaiatan antara apa yang dipelajari dengan kehidupan sosial akan memotivasi siswa untuk terus belajar sehingga hasil belajar akan meningkat.

Bila belajar IPS lebih menekankan pada hapalan, seperti dalam pembelajaran dengan menggunakan model konvensional, maka siswa akan belajar jauh dari pengalaman sehari-hari. Dengan demikian, belajar IPS seolah-seolah belajar konsep-konsep atau prinsipprinsip IPS yang tidak ada kaitannya dengan kehidupan anak. Oleh karena itu, pengetahuan anak tentang IPS sebatas pengetahuan yang ada pada buku serta apa yang diberikan oleh guru. Hal ini akan melemahkan semangat siswa untuk belajar, sehingga prestasi belajar mereka tidak tercapai secara optimal.

Di samping, didukung oleh teori, keberhasilan menolak hipotesis nol dalam penelitian ini juga didukung oleh hasil penelitian Nita Tristina (2015) yang berjudul "Pengaruh Model STM Terhadap Prestasi Belajar IPS dan Keterampilan Sosial Pada Siswa Kelas V SD Negeri Gugus II Kecamatan Seririt Tahun Pelajaran 2015/2016". Penelitian ini bertujuan untuk mengetahui besarnya pengaruh model pembelajaran sains teknologi masyarakat terhadap prestasi belajar IPS dan keterampilan sosial. Penelitian ini adalah penelitian eksperimen semu dengan rancangan The Posttest-Only Control-Group Desain. Populasi penelitian adalah seluruh siswa kelas V SD Negeri Gugus II Kecamatan Seririt Tahun Pelajaran 2015/2016 yang terdiri dari 5 SD Negeri dengan jumlah populasi 132 siswa. Sebanyak 45 siswa dipilih sebagai sampel yang ditentukan dengan teknik random sampling. Data prestasi belajar IPS dikumpulkan dengan tes pilihan ganda dan keterampilan sosial menggunakan lembar observasi. Data dianalisis dengan menggunakan MANOVA (Multivariat Analysis of Variance) berbantuan SPSS 17.00 for windows. Hasil Penelitian menunjukkan bahwa: Pertama, prestasi belajar IPS antara siswa yang mengikuti model pembelajaran sains teknologi masyarakat secara signifikan lebih baik daripada siswa yang mengikuti model pembelajaran konvensional ( $F$ sebesar 23,510 dan $p<0,05)$. Kedua, keterampilan sosial antara siswa yang mengikuti model pembelajaran sains teknologi masyarakat secara signifikan lebih baik daripada siswa yang mengikuti model pembelajaran konvensional ( $F$ sebesar 25,415 dan $p<0,05)$. Ketiga, secara simultan prestasi belajar IPS dan keterampilan sosial antara siswa yang mengikuti model pembelajaran sains teknologi masyarakat secara signifikan lebih baik daripada siswa yang mengikuti model pembelajaran konvensional ( $F$ sebesar 23,700 dan $p<0,05$ ).

Berdasarkan uraian di atas, tampaknya hasil penelitian yang diperoleh telah sesuai dengan teori yang ada dan didukung oleh beberapa penelitian sebelumnya. Dengan demikian hasil penelitian yang diperoleh melengkapi penemuan bahwa model pembelajaran STM lebih efektif dalam meningkatkan hasil belajar IPS siswa daripada model pembelajaran 
konvensional. Dengan demikian dapat disimpulkan bahwa pembelajarn dengan model pembelajaran STM berpengaruh secara signifikan terhadap hasil belajar IPS siswa kelas VII SMP Negeri 12 Denpasar

Untuk permasalahan ketiga, hasil analisis dengan manova tampak bahwa nilai FWilks' Lambda $=14,980(p=0,000<0,05)$. Oleh karena itu, hipotesis nol $(\mathrm{Ho})$ yang menyatakan bahwa tidak ada perbedaan keterampilan sosial dan hasil belajar IPS siswa secara simultan antara yang mengikuti pembelajaran dengan model pembelajaran STM dan pembelajaran konvensional pada siswa kelas VII SMP Negeri 12 Denpasar ditolak. Jadi, terdapat perbedaan keterampilan sosial dan hasil belajar IPS siswa antara yang mengikuti pembelajaran dengan model pembelajaran STM dan pembelajaran konvensional pada siswa kelas VII SMP Negeri 12 Denpasar.

Keberhasilan suatu pendidikan tidak hanya diukur dari pencapaian kognitif saja, tetapi yang lebih penting juga adalah segi afektif dan perilaku. Sikap saling menghormati dan menghargai dalam interaksi sosial baik di dalam sekolah maupun di luar sekolah perlu mendapatkan perhatian. Oleh karenanya, keterampilan sosial sangat perlu diajarkan di sekolah. Keterampilan sosial termasuk tujuan utama pendidikan untuk meningkatkan kesiapan sekolah seperti kemampuan untuk menghormati orang lain, untuk bekerja sama secara kooperatif, untuk mengekspresikan emosi dan perasaan dengan cara yang baik, untuk mendengarkan orang lain, untuk mengikuti aturan dan prosedur, untuk duduk dengan penuh perhatian, dan untuk bekerja secara mandiri.

Dalam pembelajaran IPS dengan menggunakan model pembelajaran STM, siswa dilibatkan untuk menerapkan konsep-konsep IPS pada kehidupan sehari-hari. Penerapan konsep IPS ada pada teknologi, dengan demikian siswa mengenali teknologi yang ada di sekitarnya. Kemudian dari observasi ke lingkungan siswa menemukan sendiri kesimpulan atau konsep-konsep IPS yang ada. Guru hanya membimbing siswa dalam memperoleh konsep-konsep yang dituju. Dengan demikian pengajaran IPS dengan model pembelajaran STM akan mampu meningkatkan keterampilan sosial siswa secara maksimal, dan meningkatkan sikap literasi terhadap sains dan teknologi.

Dalam pembelajaran IPS dengan menggunakan pembelajaran konvensional, lebih menekankan pada fungsi guru sebagai pemberi informasi. Siswa hanya pasif mendengarkan penjelasan guru tanpa dilibatkan secara aktif dalam pembelajaran. Guru menjelaskan dari konsep, definisi, pengertian sampai pada contoh-contoh. Siswa baru terlibat jika ada soal yang diberikan oleh guru dan lebih bersifat teks book. Kreatifitas siswa kurang berkembang, sehingga akan berakibat pada kurang maksimalnya keterampilan sosial siswa karena sangat jarang memberikan kepada siswa untuk berpendapat.

Skeel (1995:12) menyatakan bahwa tujuan yang dicita-citakan oleh social studies adalah untuk meningkatkan konsep diri individu; mengenalkan kemampuan yang berbeda dan fungsinya kepada individu-individu; memperoleh pengetahuan dan apresiasi budaya di dalam masyarakat; meningkatkan kesadaran dan apresiasi terhadap masyarakat global dan komposisinya yang multikultural; memperoleh pengetahuan mengenai masalah-masalah global; memperoleh pengetahuan mengenai peristiwa-peristiwa masa lampau dan pengaruhnya pada masa sekarang dan masa depan; memperoleh pemecahan masalah dan keterampilan-keterampilan bernilai yang memberikan dasar untuk pembuatan keputusan; memperoleh keterampilan sosial yang meningkatkan komunikasi antar individu; untuk memperoleh pengetahuan sistem ekonomi dan politik untuk partisipasi aktif; dan menumbuhkembangkan sikap yang mendorong tiaptiap individu untuk menjadi anggota yang aktif dalam masyarakat. Dengan demikian tujuan pembelajaran IPS selain kognitif adalah keterampilan sosial.

Dalam pembelajaran IPS dengan menggunakan model pembelajaran STM, siswa dilibatkan untuk menerapkan konsep-konsep IPS pada kehidupan sehari-hari. Penerapan konsep IPS ada pada teknologi, dengan demikian siswa mengenali teknologi yang ada di sekitarnya. Kemudian dari observasi ke lingkungan siswa menemukan sendiri kesimpulan atau konsep-konsep IPS yang ada. Guru hanya membimbing siswa dalam memperoleh konsep-konsep yang dituju. Dengan demikian pengajaran IPS dengan model pembelajaran STM akan mampu meningkatkan keterampilan sosial dan hasil belajar siswa secara 
maksimal, dan meningkatkan sikap literasi terhadap sains dan teknologi. Proses pembelajaran yang serius kaku tanpa sedikitpun ada nuansa kegembiraan tentulah akan sangat cepat membosankan. Apalagi diketahui bahwa berdasarkan penelitian kekuatan ratarata manusia untuk terus konsentrasi dalam situasi yang monoton hanyalah sekitar 15 menit saja. Selebihnya pikiran akan segera beralih kepada hal-hal lain yang mungkin sangat jauh dari tempat di mana ia duduk mengikuti suatu kegiatan tertentu. Untuk itu, model pembelajaran perlu dikombinasikan dengan ice breaker. Ice breaking adalah kegiatan yang berfungsi untuk mengubah suasana kebekuan dalam kelompok yang berupa permainan atau dapat dinyatakan sebagai salah satu upaya yang bisa dilakukan guru untuk membangkitkan motivasi siswa dalam belajar dan membuat suasana belajar menjadi lebih asyik dan menyenangkan dalam proses pembelajaran.

Dalam pembelajaran IPS dengan menggunakan pembelajaran konvensional, lebih menekankan pada fungsi guru sebagai pemberi informasi. Siswa hanya pasif mendengarkan penjelasan guru tanpa dilibatkan secara aktif dalam pembelajaran. Guru menjelaskan dari konsep, definisi, pengertian sampai pada contoh-contoh. Siswa baru terlibat jika ada soal yang diberikan oleh guru dan lebih bersifat teks book. Kreatifitas siswa kurang berkembang, sehingga akan berakibat pada kurang maksimalnya hasil belajar siswa

Sebagai bentuk perbandingan, pembelajaran konvensional lebih didominasi oleh kegiatan guru untuk memberikan instruksi atau ceramah selama proses pembelajaran berlangsung. Hal ini jelas akan menempatkan siswa sebagai penerima informasi yang pasif dan hanya menerima informasi dari guru. Proses pembelajaran cenderung kurang didasarkan pada pengalaman siswa. Hal ini tidak memberikan kesempatan mengembangkan konsep diri siswa. Jika proses pembelajaran kurang didasarkan pada pengalaman siswa, maka akan sulit mengembangkan pola berpikir dan kemampuan merefleksi, penguasaan pengetahuan, keterampilan proses, dan sikap ilmiah.

Hasil penelitian ini juga didukung oleh penelitian eksperimen yang dilakukan oleh Penelitian yang dilakukan Hermawan Wahyu Setiadi (2014) dengan judul "Pengaruh Model Pembelajaran Sains Teknologi Masyarakat (STM) Terhadap Hasil Belajar IPA Ditinjau dari Kemampuan Berpikir Kritis pada Siswa Kelas V SD Muhammadiyah 2 Denpasar" Penelitian ini bertujuan untuk mengetahui perbedaan hasil belajar IPA antara siswa yang mengikuti model pembelajaran STM dan model pembelajaran konvensional berdasarkan tingkatan kemampuan berpikir kritis siswa serta interaksi antara model pembelajaran dengan kemampuan berpikir kritis. Penelitian ini mengunakan rancangan faktorial $2 \times 2$. Populasi dalam penelitian ini adalah semua siswa kelas V SD Muhammadiyah 2 Denpasar tahun ajaran 2013/2014, dengan sampel sebanyak 56 siswa. Teknik sampling yang digunakan adalah random sampling. Data kemampuan berpikir kritis dan hasil belajar IPA diperoleh melalui tes kemudian dianalisis menggunakan ANAVA dua jalur dan dilanjutkan dengan tes Tukey. Hasil penelitian menunjukan bahwa: (1) terdapat perbedaan yang signifikan hasil belajar IPA antara siswa yang mengikuti model pembelajaran STM dengan siswa yang mengikuti model pembelajaran konvensional dimana $F_{\text {Ahitung }}=27.189>F_{\text {tabel }}=4.49$, (2) Terdapat pengaruh interaksi antara model pembelajaran STM dengan kemampuan berpikir kritis siswa terhadap hasil belajar IPA dimana $F_{\text {ABhitung }}=79.904>F_{\text {tabel }}=4.49$, (3) Terdapat perbedaan yang signifikan antara hasil belajar IPA siswa yang memiliki kemampuan berpikir kritis tinggi yang mengikuti model pembelajaran STM dengan siswa yang mengikuti model pembelajaran konvensional dimana $\left(Q_{\text {-hitung }}=16.047>Q_{\text {-tabel }}=4.11\right)$, (4) Terdapat perbedaan yang signifikan antara hasil belajar IPA siswa yang memiliki kemampuan berpikir kritis rendah yang mengikuti model pembelajaran STM dengan siswa yang mengikuti model pembelajaran konvensional dimana $(\mathrm{Q}$-hitung $=4.23>\mathrm{Q}$-tabel $=4.11)$. Dengan demikian dapat dinyatakan bahwa ada perbedaan keterampilan social dan hasil belajar IPS siswa antara yang mengikuti pembelajaran dengan model pembelajaran STM dan langsung pada siswa kelas VII SMP Negeri 12 Denpasar telah terbukti secara teoretis dan empiris. 


\section{SIMPULAN DAN SARAN}

Berdasarkan analisis data dan pembahasan seperti yang telah diuraikan pada bagian sebelumnya, dapat ditemukan beberapa hal sebagai berikut. (1) terdapat perbedaan keterampilan sosial siswa antara yang mengikuti pembelajaran dengan model pembelajaran STM dan konvensional pada siswa kelas VII SMP Negeri 12 Denpasar dengan F=19,414 ( $p$ $=0,000<0,05$ ); (2) terdapat perbedaan hasil belajar IPS siswa antara yang mengikuti pembelajaran dengan model pembelajaran STM dan konvensional pada siswa kelas VII SMP Negeri 12 Denpasar dengan Fhitung = 8,006 ( $p=0,0066<0,05)$, dan (3) terdapat perbedaan keterampilan sosial dan hasil belajar IPS siswa antara yang mengikuti pembelajaran dengan model pembelajaran STM dan konvensional pada siswa kelas VII SMP Negeri 12 Denpasar dengan F Wilks' Lambda $=14,980 \quad(p=0,000<0,05)$.

Berdasarkan temuan di atas dapat disimpulkan bahwa model pembelajaran STM berpengaruh secara signifikan terhadp keterampilan sosial dan hasil belajar IPS siswa kelas VII SMP Negeri 12 Denpasar.

Hasil penelitian menunjukkan bahwa model pembelajaran STM berpengaruh signifikan terhadap keterampilan sosial dan hasil belajar IPS siswa secara terpisah maupun simultan. Berdasarkan kesimpulan dan implikasi penelitian yang telah dipaparkan di atas, maka kepada guru disarankan menggunakan model pembelajaran STM sebagai upaya untuk meningkatkan keterampilan sosial dan hasil belajar IPS siswa. Dalam kegiatan belajar mengajar di kelas, guru disarankan agar tidak hanya terfokus pada satu metode mengajar saja agar peserta didik tidak cepat merasa bosan dalam kegiatan pembelajaran. Dari pemahaman tersebut, guru diharapkan dapat: (1) guru mempersiapkan media untuk mendukung metode pembelajaran, (2) sebelum menerapkan model pembelajaran, guru harus mengkondisikan siswa, agar siap berlatih berbicara bersama teman-teman di dalam kelompoknya masing-masing dengan beragam aktivitas yang harus dilakukan dan memberikan penjelasan materi yang akan dipelajari, dan (3) evaluasi secara komprehensif.

\section{DAFTAR RUJUKAN}

Bremer dan Smith. 2004. "Teaching Social Skill". International Center on Secondary Education and Transition Information Brief, October 2004. Vol.3, Issue. Hal.1.

Dimyati dan Mudjiono. 2002. Belajar dan Pembelajaran. Jakarta: Rineka Cipta

Prayekti. 2001. "Model pembelajaran Sains Teknologi Masyarakat tentang Konsep Pesawat Sederhana dalam Pembelajaran IPA di Kelas 5 Sekolah Dasar". Jurnal. http://www.depdiknas.go.id/Jurnal/29/editorial.htm.

Poedjiadi, Anna. 2005. Sains Teknologi Masyarat:Model Pembelajaran Kontekstual Bermuatan Nilai. Bandung: Remaja Rosdakarya.

Suharmawan, Wahid. 2010. Di Butuhkan Model pembelajaran Baru untuk Kehidupan Abad21.

Sumardani. 2014. "Pengaruh Penerapan Teknik Ice Breaker terhadap Hasil Belajar Peserta Didik Kelas III Sekolah Dasar Penelitian ini bertujuan untuk menganalisis pengaruh teknik Ice Breaker pada pembelajaran Matematika terhadap hasil belajar peserta didik kelas III Sekolah Dasar Negeri 20 Pontianak Selatan".

Wulandari. 2012. "Pengaruh Penggunaan Teknik Pembelajaran Ice Breaker Terhadap Kemampuan Menulis Pantun Siswa Kelas VII SMP Swasta Pahlawan Sukaramai Tahun Pembelajaran 2012/2013".

Yager, Robert Eugene. 1996. Science Technology Society As Reform In Science Education. New York: State University of New York Press 
Nita Tristina. 2015. "Pengaruh Model Pembelajaran STM Terhadap Prestasi Belajar IPS dan Keterampilan Sosial Pada Siswa Kelas V SD Negeri Gugus II Kecamatan Seririt Tahun Pelajaran 2015/2016"

Rusmansyah, Irhasyuarna, Y. 2001. "Implementasi Model pembelajaran Sains-TeknologiMasyarakat (STM) dalam Pembelajaran Kimia di SMU N Banjarmasin". Jurnal. http://www.depdiknas.go.id/Jurnal/40/editorial40.htm.

Wahyu Setiadi. 2014 "Pengaruh Model Pembelajaran Sains Teknologi Masyarakat (STM) Terhadap Hasil Belajar IPA Ditinjau dari Kemampuan Berpikir Kritis pada Siswa Kelas V SD Muhammadiyah 2 Denpasar" . Artikel. E-journal Program Pascasarjana Universitas Pendidikan Ganesha Jurusan Pendidikan Dasar (Volume 3 Tahun 2014, hal. 86). 